\title{
1898 DÜKÇÜ İŞAN İSYANI (ANDİCAN AYAKLANMASI)
}

Seda YILMAZ VURGUN*

\begin{abstract}
$\ddot{O} \mathbf{z}$
Türkistan'ın Ruslar tarafından işgalinin tamamlanmasının ardından bölgede yeni bir yönetim sistemi ve yeni bir devir başlamıştır. Bu yeni dönemde Türkistan halkı sömürülmüş ve asimile edilmeye çalışılmıştır. Sömürgecilik yarışında geri kalmamak için yayılma alanı olarak Türkistan bölgesini seçen Rusya, halkı baskı altında tutmak için elinden geleni yapmıştır. Bölgeyi hammadde kaynağı olarak görmüş ve pamuk dışında diğer ürünlerin ekilmesine izin vermemiştir. Ruslar Türkistan halkının elindeki toprakları türlü yollarla ele geçirerek Rusya'dan gelen yeni göçmenlere dağıtmışlardı. Halk Rusların yaptığı baskı ve zulümlere dayanamayarak bağımsızlıklarını elde edebilmek için harekete geçmiştir. Türkistan'da ardı ardına birçok isyan patlak vermeye başlamıştır. 1898'de Dükçü İşan'ın önderliğinde çıkan Andican ayaklanması da Türkistan bağımsızlığı yolunda önemli bir dönüm noktası olmuştur. Ayaklanma Fergana'da çıkmış, Oş ve Namangan gibi şehirlere hızla yayılmıştır. Rusya kısa sürede ayaklanmayı bastırmış ve çok sayıda insanı sürgüne göndermiştir. Önemli ayaklanma liderleri idama mahkûm edilmiş ve halkı baskı altında tutabilmek için bir dizi tedbir alınmıştır.
\end{abstract}

Anahtar Sözcükler: Andican Ayaklanması, Dükçü İşan, Türkistan, Fergana, Kırgizlar.

1898 DUKCHI ISHAN REBELION (ANDIJAN UPRISING)

\begin{abstract}
Following the full conquest of Turkestan by Russians, in the region a new ruling system and a new era have been started. In this new era, the people of Turkestan have been exploited and tried to be assimilated. In order not to fall behind in the race of exploitation Russia has chosen Turkestan Region and tried to do as much as she can to keep people of the region under pressure and control. They have considered the region as a source of raw materials and they have not let people plant anything except cotton. Russians have gained the lands of local people with various methods and have given the control of those lands to new immigrants coming from Russian motherland. Local people could not stand to those pressures and suppression coming from Russians and they started to resist and to react in order to obtain their independence back. Then in the region numerous rebellions have broken out one after another. The Andijan Uprising of 1898 which leaded by Dukchi Ishan has been one of the milestones for the way to the independence of Turkestan. The rebellion has been erupted in Ferghana and quickly been spread to the other cities such as Osh and Namangan. Russia has managed to control the uprising easily and sent many local people to exile. Prominent rebellious leaders have been executed and a serious of precautions have been taken in order to keep people under control.
\end{abstract}

\footnotetext{
* Yrd. Doç. Dr.; Bilecik Şeyh Edebali Üniversitesi Fen Edebiyat Fakültesi Tarih Bölümü, sedayilmazvurgun@hotmail.com.
} 
Keywords: Andijan Uprising, Dukchi Ishan, Turkestan, Ferghana, Kyrgyzs.

\section{Giriş}

Rusya Türkistan hanlıklarını istila etmek için XVI. asırdan itibaren sürekli seferler düzenlemişti. ${ }^{1}$ Hanlıklara karşı resmî Rus ilerlemesi 1865 yıllında başlamış ve önce Hokand, ardından Buhara ve Hive Hanlığını işgal etmişti. ${ }^{2}$ Tüm bu gelişmeler doğrultusunda Türkistan'da yaşayan Özbek, Kazak, Kırgız, Türkmen gibi birçok Türk topluluğu ortamdan etkilenmiş ve Rusların yaptıklarından rahatsız olmuştu.

Kırgızlar ile Ruslar arasındaki ilişkileri iki dönemde incelemek mümkündür. İlk dönemde Ruslar, Kırgızları fark ettirmeden kendi hâkimiyetlerine almaya çalışmışlardı. XIX. yüzyılın özellikle ikinci yarısında Kırgız kabileleri aralarındaki kavgaların ve şahsi çıkarların etkisiyle Rusya'nın hâkimiyeti altına girmek istemişlerdi. Ruslar kendi tabiiyetlerine geçmek isteyen Kırgız beylerine önemli miktarda hediye vermişlerdi. Rusya'nın hâkimiyeti altına girmek istemeyen beylerin bir kısmı da Rusya'dan çıkarı olan diğer beylerin yardımı ile ortadan kaldırılmıştı. ${ }^{3}$ Öte yandan Rus İşgalinin ilk 25 yıllında Rusya bütün çabalarına rağmen Türkistan'da düzen ve istikrarı sağlayamamıştı. Kırgızlar, Ruslara karşı küçük çapta çete mücadelelerine başlamışlardı. Ancak Ruslar, bu mücadeleleri Rus göçmenlerine yönelik yapıldığı için dikkatte almamışlardı. ${ }^{4}$

Rus - Kırgız ilişkilerindeki diğer aşama ise zorla işgal sürecini içeriyordu. Ruslar işgal ettikleri yerlere bir kolonileşme metodu olarak kaleler yapmışlardı. 1847'de Kopak Kalesi ve 1854'de Alma-Ata gibi önemli müstahkemler bu amaçla kurulmuşlardı. Pişkek, Tokmak ve 1861 'yıllında işgal edilen Isık Gölü civarı Rusların eline geçmişti. 1867 yılında Kırgızistan'ın bir kısmı Yedisu vilayetine dâhil edilerek Türkistan'a bağlanmıştı. Bir kısmı ise Sır-Derya ve Fergana vilayetleri ile birleştirilmişti. 1876'da Kırgızistan'ın güney kısmı Rusların eline geçmişti. $^{5}$

\footnotetext{
${ }^{1}$ Mehmet Saray, "Rusya'nın Türkistan'da Yayılması", Genel Türk Tarihi, C.9, Ankara, Yeni Türkiye Yayınları, 2002 , s.687.

${ }^{2}$ Mehmet Alpargu, “Türkistan Hanlıkları”, Türkler, C.8, Yeni Türkiye Yayınları, Ankara, 2002, s.987-988.

${ }^{3}$ Saadettin Gömeç, Kırgız Türkleri Tarihi, Berikan Yayınları, Ankara, 2011, s.96.

${ }^{4}$ Beatrice Forbes Manz, "Central Asian Uprisings in the Nineteenth Century: Ferghana under the Russians", Russian Review, Vol:46, No:3 (Jul., 1987), s.267.

${ }^{5}$ R.Rahmeti Arat, "Kırgızistan”, İslam Ansiklopedisi, C:6 Milli Eğitim Yayınları, İstanbul, 1977, s.739.
} 
Ruslar 1867 yılında yeni işgal edilen bölgelerle beraber Taşkent merkez olmak üzere bir Türkistan Genel Valiliği kurmuşlard. ${ }^{6}$ Türkistan Genel Valiliği’nin başına General Kaufman getirilmiş ve valilik Sır-Derya, Fergana, Semerkand, Semireçye ve Hazar-Ötesi dâhil beş bölgeye ayrılmıştı. ${ }^{7}$

Ruslar Türkistan Genel Valiliği vasıtasıyla bir taraftan halkı kontrol altında tutmaya çalışırken, diğer taraftan da hanlıkların başına getirdikleri kukla yöneticiler kanalıyla onları ezmeye ve istediklerini yaptırmaya zorlamışlardı. ${ }^{8}$

Kırgızlar tüm baskılara rağmen direnmişler ve bağımsızlık mücadelelerini Altay bölgesinde devam ettirmişlerdi. Ruslar, Kurbancan Datha adlı bir kadının önderliğinde yürütülen isyan ile uzun süre uğraşmışlardı. Kurbancan'ın hayatının sonuna kadar Kırgızların başında olması şartı ile Ruslarla bir antlaşma yapılmıştı. ${ }^{9}$ Ancak Rus baskısına dayanamayan halk 1885 yıllında tekrar isyan etmişti. Bu ayaklanmanın liderliğini Derviş Han Töre yapmıştı. Ayaklanma Rusların modern silahları karşısında başarı gösterememiş ve binlerce insan katledilmişti. $^{10}$

Rusların Türkistan bölgesindeki halka zülüm etmesi, ağır vergiler uygulaması, Türkistan'ın pamuk üretim merkezi gibi görülmesi ve Rusların verimli Türkistan topraklarına yerleştirilmesi gibi faktörler halkı olumsuz yönde etkilemişti. Bir de buna Rus görevlilerin ahlaki olmayan davranışları eklendiğinde Türkistan bölgesinde isyanlar arda arda patlak vermişti. ${ }^{11} 1898$ Andican ayaklanması ve ardından gelen 1916 isyanı bu gibi etkenlerin sonucunda meydana gelmişti.

\section{Andican İsyanının Nedenleri}

1876 yılında Ruslar Andican'ı işgal ettiklerinde nüfusu 30.000 civarında idi. Rusya’nın İç Asya’yı sömürgeleştirmek ve buradaki hanlıkları işgal etmek için başlattığı plan sonucunda

\footnotetext{
${ }^{6}$ Mustafa Erdem, Kırgız Türkleri Sosyal Antropoloji Araştırmaları, Avrasya Stratejik Araştırma Merkezi Yayınları, Ankara, 2000, s.2; Füsun Kara, “Rusya'nın Kırgızistan'daki Koloni Siyaseti: 1852-1917”, Firat Üniversitesi Sosyal Bilimler Dergisi, C.17, Sa:2, Elazığ, 2007, s.322.

${ }^{7}$ Toktorbek Ömürbekov, "Sömürge Döneminde Kırgızlar", Türkler, C.18, Çev: Liliye Sabırova, Yeni Türkiye Yayınları, Ankara, 2002, s.623.

${ }^{8}$ Saray, "Rusya'nın Türkistan'da Yayılması", s.704.

${ }^{9}$ Mehmet Saray, "Kırgızistan”, Íslam Ansiklopedisi, Türkiye Diyanet Vakfi Yayınları, C.25, Ankara, 2002, s.443.

${ }^{10}$ Gömeç, age, s.102; Saray, "Rusya'nın Türkistan'da Yayılması", s.707.

${ }^{11}$ Akdes Nimet Kurat, Rusya Tarihi; Başlangıçtan 1917’ye Kadar, Türk Tarih Kurumu Basımevi, Ankara, 1987, s.427.
} 
şehir Fergana vilayetine bağlı bir kaza hâline getirilmişti. Zamanla halk üzerinde çok yönlü bir bask1 oluşturulmuştu. ${ }^{12}$

Türkistan Genel Valiliği'’nde askeri yöneticiler uzun süre vazife görmüş; ancak zamanla Rus göçmenler ve Rusya'dan gelen yöneticiler iş başına gelmişti. Sistem oturduktan sonra kendilerine yardımcı olmaları için yerli halktan kişilere de çeşitli görevler verilmişti. 1886 yılından itibaren Rus yöneticilere istedikleri toprakları devletleştirme ve Rus göçmenlere verme hakkı verilmişti. ${ }^{13}$

Çarlık yönetimi Ruslar ve diğer Slav milletlerinden oluşan kitleleri Türkistan'a getirerek büyük bir yerleşim programını yürürlüğe koymaya başlamış, ${ }^{14}$ Orta Rusya ve Ukrayna'daki binlerce insanı Türkistan'a gelmeleri için destekleyerek bunlara genelde Kırgızlardan zorla alınan toprakları vermişti. Rus göçmenlerin bir kısmı zorla getirilmiş, diğer bir kısmı ise çabuk yükselme arzusu ve yeni bir kültür getirerek bölgeyi daha medeni hâle getireceklerine inanarak Türkistan'a gelmişti. ${ }^{15}$ Ancak Türkistan halkı topraklarına Rus göçmenlerin yerleştirilmesinden memnun olmamışt1. ${ }^{16}$

İlk göç 1868 yılında gerçekleşmişti. 1868 - 1883 yılları arasında 2.500 aile Kırgız topraklarına yerleştirilmişti. ${ }^{17} 1890$ yılında Oş ve Andican kasabalarında Rus yerleşimcileri için alanlar kurulmuş ve bu sahalara gelip yerleşen Rusların sayısı 1897'de 20.000 e ulaşmıştı. ${ }^{18}$ Ruslar ilk yerleşimcilerini genelde köylere yerleştirerek ${ }^{19}$ sulamaya elverişli toprakları alma işine devam etmişlerdi. ${ }^{20}$ Türkistan'da diğer halklar içinde tarım alanında en az haklara Kırgızlar sahip olmuşlar ve çok büyük oranda toprak ellerinden alınmıştı. ${ }^{21}$

\footnotetext{
12 Enver Konukçu, "Endican”, İslam Ansiklopedisi, Diyanet Vakfı Yayınları, C.11, İstanbul, 1995, s.191; Mehmet Saray, "Kırgızistan", s.443.

${ }^{13}$ Mehmet Saray, Modern Kirglzistan 'in Doğuşu, Ankara, 2004, s.71.

${ }^{14}$ Saray, "Rusya'nın Türkistan'da Yayılması", s.703.

${ }^{15}$ Rafis Abazov, "Çarlık Yönetimi Altında Kırgızlar”, Türkler, C.18, Çev: Özgür Çınarl1-Ahmet Karan, Yeni Türkiye Yayınları, Ankara, 2002, s.607, 610.

${ }^{16}$ Muhammed Zâhir Bigi, Mâverâunnehir'e Seyahat, Çev: Ahmet Kanlıdere, Kitabevi Yayınları, İstanbul, 2005, s.117.

${ }^{17}$ Saray, Modern Kirgızistan'ın Doğuşu, s.72.

${ }^{18}$ Kara, agm., s.334.

19 Şevki Kayaoğlu, "Rus Göç Siyasetinin Yeni Uygulamaları Karşısında Türkistanlıların Görevi”, Türkistan’ın Bă̆ımsızlı̆̆ına Hizmet Eden Yeni Türkistan'dan Seçilmişs Makaleler (1927-1931), Ayaz Tahir Türkistan İdil-Ural Vakfi, İstanbul, 2005, s.114.

${ }^{20}$ Kara, agm., s.335.

${ }^{21}$ Djnish Djunushaliev, “Kırgızistan'da 1916 İsyanı”, Türkler, C.18, Çev: Alesker Aleskerov, Yeni Türkiye Yayınları, Ankara, 2002, s.628.
} 
Türkistan topraklarında Kırgız işçilere kötü davranarak onları sömüren bir kısım izinsiz yeni gelen Rus göçmeni ile Kırgız halkı arasında münakaşalar olmuştu. ${ }^{22}$ Tüm bu göç dalgalarına rağmen Kırgızlar etnik bakımdan başka milletlerle karışmadan varlıklarını devam ettiren nadir uluslardan biri olmuştu. ${ }^{23}$

Ruslar Kırgızistan'ın verimli topraklarını almakla yetinmemiş ayrıca halka ağır vergiler de yüklemişlerdi. Ruslar, Kırgızistan'dan haraç ve tanap denilen iki yarı türde vergi talep etmişlerdi. Haraç; ekilen topraklarda yetiştirilen ürünün \%10’u iken, Tanap; bağ ve bahçelerde ekilen ürünün \%10’u ile \%20'si arasındaki vergi idi. Hayvancılıkla uğraşan Kırgızlardan da aile başına 1,5 ile 4 rublelik vergiler alınmıştı. Vergiler giderek artmış sonunda Kırgız halkı çok zor duruma düşmüştü. ${ }^{24}$ Kırgız halkının topraklarını kaybetmesine paralel olarak büyük baş hayvan yetiştiriciliği de bitmişti. ${ }^{25}$

Amerika Birleşik Devletleri'nde iç savaşın başlamasının etkisiyle pamuk fiyatları artmış ve Ruslar Türkistan'a bir tür Amerikan pamuğu ekmişlerdi. Bundan sonra pamuk ekilen alanlar ve Rusya'ya pamuk sevkiyatı hızla artmıştı. ${ }^{26}$ Rus fabrikatörler Türkistan bölgesinde halka kötü oyunlar oynayarak pamuk alanlarındaki üreticileri iflasa sürüklemişler ve sonuçta 1893 - 1898 yılları arasında ekonomik buhran gerçekleşmişti. ${ }^{27}$ Ayrıca Rusya pamuk ekimi yapanlara artan bir şekilde daha fazla ücret ödediği ve pamuğun ekimi hububata göre daha kolay olduğu için Türkistan'da hububat ekimi giderek azalmış ve sonunda Türkistan halkı hububatının çoğunu Rusya'dan alır hâle gelmişti. ${ }^{28} \mathrm{Bu}$ suretle bir tarım memleketi olan Türkistan'ın, ${ }^{29}$ Rusya'nın hammadde pazarı ve hazır mal pazarına dönüşmesi, özellikle Fergana vilayetinde halkı her açıdan kötü bir duruma düşürmüştü. ${ }^{30}$

Rusların sürekli artırdıkları vergileri ödemek zorunda olan Fergana halkının bir kısmı çevrelerinde kurulan az sayıda sanayi kuruluşuna işçi olarak girmişti. Tarımla uğraşanlar da

\footnotetext{
${ }^{22}$ Abazov, agm., s.611.

${ }^{23}$ Seyfettin Erşahin, Kırgızlar ve İslamiyet: Göçebe Bir Türk Boyunun İslamlaşma Tarihi Üzerine Bir Deneme, Sek Yayınlar1, Ankara, 1999, s.17-18.

${ }^{24}$ Saray, Modern Kırgızistan'ın Doğuşu, s.72.

${ }^{25}$ Kara, agm., s.336-337.

${ }^{26}$ Elizabeth E. Bacon, Esir Orta Asya, Tercüman 1001 Eser, İstanbul, s.119-120.

${ }^{27}$ Togan, age., 332.

${ }^{28}$ Sir Olaf Caroe, Sovyet Imparatorluğu Sömürülen Topraklar, C.1, Çev: Zerhan Yüksel, Tercüman Yayınları, İstanbul, s.148-149; Bacon, age., s.120.

${ }^{29}$ Baymirza Hayit, Esir Türkler: Türkistan'da Sovyet-Rus Sömürgeciliği ve Emperyalizmi, Asya'da Müslüman Halk Üzerinde Uygulanan Sovyet Sömürgeciline Bir Örnek, Kişisel Kitaplar, Ankara 1996, s.116.

${ }^{30}$ Hamid Ziyayev, Türkistan'da Rus Hâkimiyetine Karşı Mücadele: XVIII-XX. Asır Başları, Çev: Ayhan Çelikbay, Ankara, 2007, s.342.
} 
$612^{*}{ }^{\text {TAED }} 54$

Seda YILMAZ VURGUN

sürekli pamuk ekmek zorunda kalarak, Rusların işçileri hâline getirilmiş ve sürekli sömürülmüştü. ${ }^{31}$

İsyanın en önemli unsurlarından biri de Türkistan'da manevi hayatı şekillendirmede temel güç olan İslam dininin küçümsenmesi ve ayrıca maddi temellerine sınırlandırılma getirilmesi olmuştu. İslam dininin, Müslüman olmayanların oyuncağı olması ve namaz vakitlerinde Rus imparatoru adına zorunlu olarak hutbe okutulması halka büyük acı vermişti. Rus hükümeti İslam dinini baskı altına almaya çalışmış ve din adamlarını köşeye sıkıştırmak için elinden geleni yapmıştı. ${ }^{32}$ Kadılık, aksakallık gibi görevlere kendileri için kukla olan insanları getirmeye özen göstermişlerdi. ${ }^{33}$

25 kadı ve müftü eski mezarlıklarının yıkılmaması ile ilgili bir dilekçe vermişler ise de bu talep yerine getirilmediği gibi Ruslar tarafından görevden alınmışlardı. Ayrıca Ruslar isyan çıkmasından endişe duydukları için din adamlarının herhangi bir karışıklığa katılmaları durumunda bazı yaptırımlara maruz kalacaklarını duyurmuşlardı. Bu yaptırımlar medreselerin kapatılması ve vakıf topraklarının devlete geçirilmesini içeriyordu. ${ }^{34}$

Rusların yaptığı bazı düzenlemeler yerel kanunlarla çelişiyordu. Rusça eğitim veren okulların açılması, ${ }^{35}$ yeni basılan Kuran-1 Kerim'lerde ve kitaplarda kâfir adının kaldırılması da Müslümanları huzursuz eden faktörlerden olmuştu. ${ }^{36} \mathrm{Bu}$ zulümlerden bıkan din adamaları isyanı desteklemiş ve bu şekilde millî mücadelenin manevi yönü de tamamlanmıştı.

$\mathrm{Bu}$ çerçevedeki önemli bir diğer faktör de Nakşibendîliğin etkisiydi. Bölgedeki Nakşibendîlik gibi tarikatların Rus hâkimiyetine karşı gösterdikleri direncin yanında halkı mücadeleye davet etmeleri de isyanda önemli etkenlerden biri olmuştu. İşanların ${ }^{37}$ halk üzerindeki etkisi büyüktü. Birçok İşan kendilerini yerel hanların varisleri olarak kabul ettikleri için düşman işgali karşısında Türkistan halkını silaha sarılmaya teşvik etmişti. ${ }^{38}$ Rus işgalinden sonra Fergana bölgesine gelen İşanlar sufîzmi yaymaktan ziyade kutsal cihad propagandasına

\footnotetext{
${ }^{31}$ Bacon, age., s.102-121.

${ }^{32}$ Ziyayev, age., s.345; Sebahattin Şimşir, Dünden Yarına Türkistan'da Türkler, Kültür Sanat Yayıncılık, İstanbul, 2009, s.219.

${ }^{33}$ Şimşir, age., s.219; Saray, “Rusya’nın Türkistan'da Yayılması”, s.703.

${ }^{34}$ Şimşir, age., s.220.

35 Seyit Sertçelik, "Rus İmparatorluğu'nun Avrupa Yakasında Yaşayan Türklerin Demografik Dağılımı ve Çarlık Rusya'sının Türklere Yönelik Politikaları", Genel Türk Tarihi, C.9, Yeni Türkiye Yayınları, Ankara, 2002, s.628.

${ }^{36}$ Anke Von Kuelgen, "Andijan Uprising”, Encyclopaedia Iranica, (http://www.iranicaonline.org/articles/andijanuprising) 2004.

37 İşan: Bölgenin dini hayatında söz sahibi olan yerel sufi liderlerdir.

38 Süleyman Derin, “Tasavvufun Orta Asya'da Yakın Geçmişteki Rolü: Kırgızistan Örneği”, İlmi Akademik Araştırma Dergisi, Sa: 16, 2006, s.18-19.
} 
ağırlık vermişlerdi. İşanlar Ruslara karşı isyan çıkarabilmek için murid elde etmeye çalışmışlardı. Bölgede çıkan tüm isyanlarda İşanların etkisi olmuştu. İşanların organize ettiği en büyük ayaklanma 1898 Andican ayaklanmasıydı. ${ }^{39}$

Dükçü İşan bir Nakşibendî şeyhi idi. 1882 y1lında Nakşibendî şeyhi Tura Han öldüğünde Dükçü İşan onun yerine Nakşibendî lideri olmuştu. Tura Han'ın çocukları Dükçü İşan'ın babalarının yerine geçmesine itiraz etmişlerdi. Ancak Dükçü İşan onlara Tura Han'ın imzalayıp damgaladığı kendisinin onun yerine geçtiğini gösteren belgeyi (icazetname) göstermiş̧it.

Dükçü İşan Mingtepe'de kendini kutsallaştırmayı başarmıştı. Andican'ın $35 \mathrm{~km}$. güneyinde bulunan Mingtepe'de onun takipçileri bir hangâh yapmıştı. Bir kaç düzine insan onun koruması ve hizmetkârı idi. Her gün 300-500 kişi hangâha ders, nasihat, destek alma ve tedavi için gelirdi. Günlük 1000 kişiye yakın insan bu hangâhda yemek yerdi. Takipçileri Fergana vadisinde yer alan bütün etnik guruplardan oluşuyordu. ${ }^{40}$ Ancak şehirli halk içinden destekçi sayısı düşüktü. Dükçü İşan'ın senede bir kez Kırgız takipçilerini ziyaret ettiği Kırgizistan'ın güneyinde aktif bir merkezi daha vardı. ${ }^{41}$

Ayrica isyanda hanlık zamanında unvan ve imtiyazlara sahip olan ancak Ruslar geldikten sonra bu haklarından mahrum edilen insanların etkisi de göz ardı edilemezdi. Onlar sakin günlerde sessiz kalmışlar, yeni vergiler konulduğunda ve hükümet yeni düzenlemeler yaptığında halkı isyan etmeleri için harekete geçirmişlerdi. ${ }^{42}$

Türkistan'daki Rus subayları rahat durmamış yükseklik duygusu ile halkı hakir görerek onlara zulmetmişlerdi. Rus subaylar burada kendilerini tamamen içkiye vermişler ahlaksızlık ve her türlü rezaletin öncüsü hâline gelmişlerdi. Rahat bir şekilde hayatlarını sürdürmek isteyen subaylar daha çok paraya ihtiyaç duyduklarında kendilerine bağlı memurlardan halka kadar uzanan bir rüşvet zinciri oluşturmuşlard. ${ }^{43}$

Semerkant gibi şehirlerdeki Ruslar Türkistan halkına yönelik muameleyi iyice abartmış kendilerine şeyhler gibi davranılmasını istemişlerdi. Rus memurlar geçerken halk ayağa kalkar, ellerini birbirine bağlayıp selam verirlerdi. Ayrıca Rus memurları taşıyan arabalara yol açılır ve

\footnotetext{
${ }^{39}$ Derin, agm, s.32.

${ }^{40}$ Babadžanov, agm., s.178-180; Kuelgen, agm; Manz, agm., s.276.

${ }^{41}$ Kuelgen, age.

${ }^{42}$ Ziyayev, age., s.345; Kuelgen, agm.

${ }^{43}$ Saray, Modern Kırgızistan'ın Doğuşu, s.73-74; R. A. Pierce, Central Asia 1867-1914: A Study in Colanial Rule, California, 1960, s.69-71.
} 
geçmesi beklenirdi. Ruslar kendi ülkelerinde yapamadıkları birçok uygulamayı Türkistan halkı üzerinde baskı aracı olarak kullanmışlardı. ${ }^{44}$

Türkistan Genel Valisi General Kaufman subayların ahlaksız hâllerine inanmak istememiş ve bir müddet sonra "benim subaylarım bu kadar ahlaksız olmaz" deyip hadiseleri araştırmıştır. ${ }^{45}$ Ancak zaman geçtikçe Türkistan halkına Rus memurların yaptığı kötü muameleyi saklayamayan Rusya General Kaufman'1 görevden alarak yerine önce General Çernyayev'i daha sonra ise General Rosenbach'1 gerekli 1slahatları yapması için görevlendirmişti. ${ }^{46}$ Tüm bu olumsuz koşullar altında Andican'da 1898 yılında bir isyan gerçekleşmişti.

\section{Andican İsyanının Başlaması ve Gelişmesi}

İsyanda etkili olan kişi asıl adı Muhammed Ali Sabıroğlu olan Dükçü İşan’dı. Babası pamuğu sapından ayıran hallaç ve dükçü ${ }^{47}$ beşikleri yapan bir ustaydı. ${ }^{48}$ Kendisi de ip ustası olup ilmi az; ancak takvası çok idi. Boş bir tepe üzerine evini yaparak burayı yeşillendirmiş ve gelip geçen yolculara su vermişti. Dağlı Kırgızlar kendisini çok sevmişler ve onunla ilgili menkıbeler ortaya çıkmıştı. ${ }^{49}$ Dinî alanda çok büyük bir şöhrete sahip olmuştu. ${ }^{50}$ Dükçü İşan Andican'ın Mingtepe Camii imamı idi.

1896 yılına gelindiğinde onbinlerce müridi vardı. Rus göçmenlerinden zarar gören Ketmen Tepe ve Kögart Kırgızları ayrıca Eseke civarındaki bütün Özbekler kendine tabiydi. Kırgız uluları gelip İşana başvurmuşlar ve kendisinin çıkaracakları isyana önderlik etmesini istemişlerdi. ${ }^{51}$ Dükçü İşan ilk başlarda kolonicilere karşı kuvvet kullanılmamasından yanaydı. Dükçü İşan'ın ayaklanmanın çıkmasını engelleyecek bir durumu da yoktu. Çünkü Kırgızlar topraklarını alan Rus yerleşimcileri dövmeye başlamışlardı. Kırgızların bir kısmı Ruslara karşı diğer Kırgızların şiddet kullanmasını engellemeye çalışsalar da başarılı olamamışlardı. Siyasi çatışmalar çoktan başlamıştı.

\footnotetext{
${ }^{44}$ Bigi, age., s.112.

${ }^{45}$ Pierce, age., s. 69-71.

${ }^{46}$ Mehmet Saray, Yeni Türk Cumhuriyetleri Tarihi, Türk Tarih Kurumu Yayınları, Ankara, 1996, s.232.

${ }^{47}$ Dükçü: İpekçi veya eğrikçi anlamlarına gelmektedir.

${ }^{48}$ Ziyayev, age., s.345.

${ }^{49}$ Baxtiyar M. Babadžanov, "Dükči İşan Der Aufstand Von Andižan", Muslim Culture in Russia and Central Asia From the 18th to the Early 20th Centuries, Klaus Schwarz Verlag, Berlin, 1998; Togan, age., s.333; Caroe, age., s.152.

${ }^{50}$ Geoffrey Wheeler, The Modern History of Soviet Central Asia, London, 1964, Manz, agm., s.89; s.276.

51 Togan, age., s.333.
} 
$\mathrm{Bu}$ gibi faktörlerin etkisi ve Rus hükümdarlığı altında ahlaki değerlerin düşmesi onun isyan fikrine sıcak bakmasına neden olmuştu. ${ }^{52}$ Şeyh, Fergana ahalisinin de kendi taraflarına çekilmesini istemişti.

Rusya'dan kârı olan Türkistanlılar bu ayaklanmayı engellemeye çalışmış; ancak Kırgızlar sürekli isyan çıkarmak için mücadele etmişlerdi. ${ }^{53} \mathrm{Bu}$ isyanın oluşma safhası yarı göçebe Kırgızlar tarafından düzenlenmişti. ${ }^{54}$

1897 y1lında Dükçü İşan'ı bir grup ziyaret edip isyan tarihini belirlemesini istemişti. Dükçü İşan daha sonraki seneyi beklemelerini söylemişti. 11 Mayıs 1898 yılında ise bir toplantı olmuş ve Dükçü İşan'a isyanı başlatması için baskı yapılmıştı. Ancak hazır olunmamasına rağmen İşan baskılara dayanamamışt1. ${ }^{55}$

Dükçü İşan zulme uğramış ve toprağı alınmış fakirler için bir inanç sembolüne dönüşmüştü. Halkın derdini ve sıkıntısını iyi bir şekilde anlamış olan Dükçü İşan, halka önder olma görevini üstüne almıştı. $\mathrm{O}$, bu isyanın başarılı olmasını ve halkın bağımsızlığını kazanmasını kutsal bir görev olarak görmüştü. ${ }^{56}$

Dükçü İşan, isyanı çıkarmak için hazırlık çalışmalarına başlamıştı. Bir bildiri yayınlayarak Rusların halk arasında içki içmeyi ve fuhuşu yaydığını, mescit ve medreseleri kapatmaya çalıştığını ve İslam dinine zarar vermeyi amaçladığını söyleyerek halkı bu haksızlığa karşı isyana çă̆ırmıştı. ${ }^{57}$

İsyanın hazırlıkları iki yıl devam etmişti. 30 Mayıs günü silahlanmış olan köylüler Dükçü İşan’ı evinden zorla çıkarıp bazı kaynaklarda beyaz veya gri at bazı kaynaklarda ise keçe üzerinde han ilan etmişlerdi. ${ }^{58}$

Kırgızlar tarafından Dükçü İşan halife olarak da ilan edilmişti. Kendisine giden halifelik belgesini Dükçü İşan imzalamıştı. Dükçü İşan halife olduktan sonra bir duyuru yaparak isyana katılan bütün Müslümanların gazilik veya şehitlik mertebesine yükseleceğini belirtmişti. ${ }^{59}$ Fergana vilayetinde ikamet eden bütün yerli halk temsilcileri özelikle Özbekler, Tacikler ve

\footnotetext{
${ }^{52}$ Kuelgen, agm; Babadžanov, agm., s.180, 183.

${ }^{53}$ Togan, age., s.333.

${ }^{54}$ Kuelgen, agm. Manz, agm., s.277.

${ }^{55}$ Babadžanov, agm., s.183.

${ }^{56}$ Ziyayev, age., s.346-347; Şimşir, age., s.220; C. E. Bosworth, “Andejan”, Encyclopedia Iranica, Vol: II, London, 1987, s.24.

${ }^{57}$ Saray, Modern Kirgızistan'ın Doğuşu, s.80; Kuelgen, agm; Gömeç, agm., s.102.

${ }^{58}$ Caroe, age., s.152; Togan, age., s.333; Babadžanov, agm., s.183.

${ }^{59}$ Babadžanov, agm., s.182.
} 
Kırgızlar Mingtepe'ye davet edilmişti. Müslümanları Ruslardan kurtarmak için Dükçü İşan'ın görevlendirildiği bildirilip bütün Müslümanlar yardıma çağrılmıştı. ${ }^{60}$

Ancak İşan’ın isyana davet çağrısı sadece Kırgızlar arasında ses getirmişti. Bazıları bu konuya uzak kalmış ve isyana katılmayacaklarını net bir şekilde bildirmişlerdi. Diğerleri ise daha fazla silah ve hazırlık olmadan böyle bir mücadeleye girmeyeceklerini belirtmişlerdi. İşan'ın müritlerinin sayısı düşünülecek olursa sadece az bir miktarı isyana kayıtsız şartsız katılmayı kabul etmişti. ${ }^{61}$

Beyannameye Molla Ahmed Nayip Molla Mirzaoğlu, Arzıkulbay Pansad, Hayıtbay Toksaba, Batır Mingbaşı, Sattıbay Mirza, Batır Mingbaşı Narmetoğlu, Muhammed İbrahim Toksaba ve Alibek Dadhah gibi önemli isimler imza atmıştı. Yerli halk temsilcilerinin aralarında bir kadı ve yardımcısı, iki ilçe başkanı ve 7 köy muhtarı vardı. Davetiyeye 11 kişi imza atmıştı ve bazı planlar da yapılmıştı. İsyan başarıyla sonuçlandığı takdirde Dükçü İşan'ın yeğeni olan 14 yaşındaki Abdülaziz hanlık tahtına çıkarılacaktı. ${ }^{62}$

Dükçü İşan ve ayaklanmanın diğer önderleri ayaklanmanın kazanılmasına yönelik bazı planlar yapmışlardı. Andican ayaklanması sırasında başka bölgelerde de isyan çıkartılacaktı. Margılan'da İnayethan Töre ve Oş’ta Ömerbek Dadha'nın komutasında isyan başlatılacaktı. ${ }^{63}$ Ancak Oş’daki ayaklanma, Ruslar önceden haber aldıkları için başarılı olamamıştı. Namangan'da ise Ruslar bir parti dolayısı ile geceyi ayakta geçirmişlerdi. Bu nedenle ayaklanma etkili olmamıştı. ${ }^{64}$

İsyan bütün Türkistan için en mühim merkez sayılan Eseke istasyonu civarında çıkmıştı. Ancak dayandığı temel nokta Ketmen Tepe ve Kögart Kırgızları idi. ${ }^{65}$ Fergana'nın ardından isyan Oş, Namangan ve Margilan'a kadar yayılmıştı. İsyan başladığı zaman Dükçü İşan'ın yanında yaklaşı 2.000 kişi bulunmaktaydı $1{ }^{66}$ İsyanın finansal yönü Nakşibendîler tarafından sağlanmıştı. İsyana Rus baskısından bıkan zengin ve fakir birçok insan katılmıştı. ${ }^{67}$

\footnotetext{
${ }^{60}$ Ziyayev, age., s.347.

${ }^{61}$ Kuelgen, agm; Babadžanov, agm., s.182.

62 Ziyayev, age., s.347; Manz, agm., s.277.

${ }^{63}$ Ziyayev, age., s.352.

${ }^{64}$ Manz, agm., s.277.

${ }^{65}$ Zeki Velidi Togan, Bugünkü Türkili ve Yakın Tarihi: Batı ve Kuzey Türkistan, C.1, İstanbul, 1981, s.332.

${ }^{66}$ Adeeb Khalid, The Politics of Müslim Cultural Reform Jadididsm in Central Asia, University of California Press, Berkeley, 1999, s.56. Manz, agm., s.277.

${ }^{67}$ Edward Allworth, Central Asia 130 Years of Russian Dominanace, A Historical Overview, Duke Üniversity Press, London, 1944, s.167-169.
} 
İsyandan bir gün önce Dükçü İşan ve müritleri hangâhda sema ve zikir yapmışlardı. ${ }^{68}$ Rus çarının baskı ve zulmünden kurtulmak için halk harekete geçmişti. ${ }^{69}$ İsyancılar 17 Mayıs gecesi 1.500 askerin bulunduğu Rus garnizonuna saldırmışlardı. İsyancılar Ruslarla mücadele etmek için kılıç, bıçak, telgraf teli ve çubuk gibi modern olmayan aletleri kullanmışlardı. ${ }^{70}$ Ruslar ayaklanmayı kanlı bir şekilde bastırmışlardı. Plana göre ayaklanma Haziranın ilk haftasında olacaktı. Ancak isyanın planlanan tarihten iki hafta önce gerçekleşmesi nedeniyle isyan çabuk bastırılmıştı. ${ }^{71}$

Ayaklanmanın sonucunda Ruslardan 22 ölü ve 20 yaralı vard1. ${ }^{72}$ İşan ve diğer ayaklanma liderleri yaralı olarak ele geçirilmiş ve 11 Haziran 1898'de ayaklanmaya katılanların mahkemesi yapılmıştı. ${ }^{73}$ İsyana iştirak edenlerden $356 \mathrm{Kurgız}, 126$ Özbek, 17 Kaşgarlı ve 5 Tacik askeri mahkemeye verilmişti. Bunlardan 18'i, bazı kaynaklarda 21'i idama ${ }^{74}$, 38'i kürek cezasına çarptırılmıştı. ${ }^{75} 360$ kişi cezalarını çekmeleri için Sibirya'ya sürgüne yollanmıştı. ${ }^{76}$ Ruslar Andican şehrindeki kadın ve çocukları zorla toplamış onların gözü önünde Dükçü İşan'1 idam etmişlerdi. ${ }^{77}$ Dükçü İşan'ın ölümünden sonra müritlerinden bir kısmı ona bağl1lıklarını inkâr etmişlerdi. $^{78}$

Ayaklanmanın ardından Çar II. Nikola'nın emriyle Mingtepe köyü yerle bir edilmiş ve adı Rus köyü olarak değiştirilmişti. Türkistan Genel Valisi Duhovskiy Andican şehrini ziyaret ettiğinde halkı diz çökmeye mecbur etmişti. ${ }^{79}$ Andican, Oş ve Margilan'da halka ağır vergiler yüklenmişti. ${ }^{80}$ İsyanın çıktığı bölgelerdeki halk zorla yerlerinden kovulmuştu. Böylece Ruslar iyi sulanan ve önemli derecede pamuk veren toprakları elde etmişlerdi. ${ }^{81}$ Andican'ın Kögart vadisindeki topraklar zorla Ruslar tarafından alınmıştı. ${ }^{82}$

\footnotetext{
${ }^{68}$ Babadžanov, agm., s181.

69 Baymirza Hayit, "Türkistan Çarizmden Bolşevizm Hâkimiyetine Geçiş Devrinde”, Türkistan'da Yenilik Hareketleri ve İtillaler 1900-1924, Ed: Timur Kocaoğlu, Haarlem, 2001, s.179.

${ }^{70}$ Kuelgen, agm; Khalid, age., s.54; Saray, Yeni Türk Cumhuriyetleri Tarihi, s.236; Babadžanov, agm., s.184.

${ }^{71}$ Abdülkadir İnan, "Dükçü İşan İsyanı", Türk Kültürü, Türk Kültürünü Araştırma Enstitüsü Yayınları, Sa: II, Ankara, Eylül 1963, s.10; Saray, “Rusya'nın Türkistan'da Yayılması”, s.707-708.

${ }^{72}$ Khalid, age., s.54; Manz, agm., s.277.

${ }^{73}$ Konukçu, age., s.192; Mirza Bala, Endican, İslam Ansiklopedisi, Milli Eğitim Yayınları, C.4, İstanbul, 1988, s.269.

${ }^{74}$ Ziyayev, age., s.354; Kuelgen, agm.

75 İnan, agm., s.10.

${ }^{76}$ Khalid, age., s.54.

${ }^{77}$ Kuelgen, agm, Şimşir, age., s.22.

${ }^{78}$ Babadžanov, agm., s.181.

${ }^{79}$ Baymirza Hayit, Türkistan Devletlerinin Milli Mücadele Tarihi, Türk Tarih Kurumu Yayınları, Ankara, 1995, s.190-191.

${ }^{80}$ Konukçu, age., s.192; Bala, agm., s.269.

${ }^{81}$ Allworth, age., s.169.

${ }^{82}$ Kara, agm., s.337.
} 
Rus genel valisinin güçleri artırılmış ve yerel hâkimleri görevlerinden alma yetkisi verilmişti. ${ }^{83}$ Hokand halkının dini ve devleti için gözünü kırpmadan ölüme gittiğini gören Ruslar, bir yandan askeri birlikleri takviye ederken bir yandan da bölgeye yerleştirdikleri Rus göçmenleri silahlandırmışlardı. ${ }^{84}$ Rusların tüm bu önlemlerine rağmen küçük guruplar hâlindeki Kırgızlar, Rus yöneticilere pusu kurmaya devam etmişlerdi. ${ }^{85}$

1898 Andican isyanından önce yerli volost ${ }^{86}$ başkanları Rusça bilmiyordu. Rus yöneticiler de dil bilmedikleri için Tatar, Başkurt ve Kuzey Kazakları tercüman olarak kullanıyorlardı. Andican ayaklanmasından sonra bütün yazışmalar Rusça yapılmaya başlanmış ve yerel yöneticilerden yanlarında Rus yazıcıları bulundurmaları istenmişti. Yazıcılar genelde Rus yerli okulu mezunlarından seçilmişti.

1898 Andican ayaklanması sonrası bölgeye vali olarak atanan Duhovsky yazdığı raporda ilk fırsata halkın Ruslara karşı tekrar ayaklanabileceğine kanaat getirmişti. Bu nedenle Müslüman nüfusun kontrol altında tutulması ve dikkatli bir şekilde gözlenmesi gerektiğine dikkat çekmişti. ${ }^{87}$

Rus aydınlar ve tarihçilerin büyük bir kısmı bu isyanı olumsuz karşılamıştı. Dükçü İşan isyanının yenilik ve medeniyet getiren Ruslara yapılmış düşmanca bir hareket olduğunu savunmuşlard1 ${ }^{88}$ Ruslar kendi kültürel ve maddi güçlerinden o kadar eminlerdi ki insanların yaşamlarını kolaylaştırdıklarına inanıyorlardı. ${ }^{89}$ Türkistan bölgesini ziyaret eden New York Herald gazetesinin muhabiri MacGahan Rusların Türkistan seferine katılmış ve Rusların Türkistan'da medeniyet getirmekten uzak olan katliamlarını tarafsız bir şekilde eserinde yazmışt. ${ }^{90}$

İsyandan sonra Kırgız Türklerine, Rus istilasının faydaları uzun uzun anlatılmıştı. Ruslar ekonomik ve kültürel anlamda dağılmakta olan Kırgız boylarının arasındaki savaşın son bulduğunu, köleliğin ortadan kaldırılarak birçok alanda ilerleme sağlandığını iddia etmişlerdi. Ancak aksine Kırgızların hayatında bir değişim olmamış ve birçok tabii hakları ellerinden alınarak zor duruma düşürülmüşlerdi. Yönetim ve kültürel alanda yapılan reformlara rağmen

\footnotetext{
${ }^{83}$ Kuelgen, agm.

${ }^{84}$ Saray, Yeni Türk Cumhuriyetleri Tarihi, s.236.

${ }^{85}$ Kara, agm., s.336-337.

${ }^{86}$ Volost: Bir toprak ve yönetim birimine verilen Rusça ad.

${ }^{87}$ Wheller, age., s.89.

88 İnan, agm., s.11.

${ }^{89}$ Wheeler, age., s.89.

90 İ. A. MacGahan, Hive Seyahatnamesi ve Tarihi Musavver, Akademi Kitabevi, İzmir, 1995.
} 
isyanın çıkmasının altında yatan nedenleri anlamak istemedikleri için farklı yorumlarda bulunmuşlard..$^{91}$

Rusların diğer bir kısmı da bu ayaklanmayı sufîlerin güç ve ideolojilerine dayanan dinî bir savaş olarak görmüşlerdi. Bu nedenle ayaklanma çok sert şekilde bastırılmış ve katı bir Rus politikasına yol açmışt1. ${ }^{92}$

Diğer yandan Rus yazarların bir kısmı isyanı daha farklı yorumlamıştı. İngiliz ve Osmanlı temsilcilerin kışkırtması ve desteği ile Andican ayaklanmasının çıkarıldığına dair bir görüş Rusların bir bölümü tarafından desteklenmişti. ${ }^{93}$ Osmanlı İmparatorluğu'nun Fergana'ya Pan-İslamizm'i yaymak için ajanlar gönderdiği ve bu ajanların bölgede karışıklık çıkarmak istediklerini de belirtmişlerdi. ${ }^{94}$ İşan'ın etrafındaki güvenilir bazı adamlar II. Abdülhamid'e bir mektup göndermişlerse de bu mektup yerine ulaştırılmamıştı. ${ }^{95}$ Rus Tümgeneral Korolkov hazırladığı raporda Dükçü İşan'ın Osmanlı Devleti ile bir ilişki içinde olmadığını; ancak İstanbul'dan getirilen kitapların etkisiyle isyanın fikri sahasının dolaylı yollardan oluştuğunu vurgulamıştı. ${ }^{96}$

Dükçü İşan ayaklanmasına Türkistan Müslümanlarının gösterdiği tepkiler farklı olmuştu. Türkistan Müslümanlarının bir kısmı ayaklanmanın çıkmasından memnun olmamıştı. Çünkü ayaklanma sonucunda Rusların kendilerine gösterdikleri baskının artacağını düşünmüşlerdi. Diğer bir kısmı ise isyanın yapılan Rus zulmünden dolayı haklı bir şekilde geliştiğine inanmıştı. ${ }^{97}$

\section{Sonuç}

İngilizlerin Hindistan üzerinde tam olarak kontrolü sağlamalarının ardından Ruslar Türkistan'1 kontrol altına alma meselesi ile yakından ilgilenmeye başlamışlardı. Kırım savaşındaki (1865-1856) yenilginin ardından Çar II. Alexsander'ın isteğiyle Rusya'nın Türkistan'da ilerlemesi hız kazanmış ve Orta Asya çok yönlü olarak işgale başlanmıştı.

XIX. yüzyılın sonunda çarlığın Orta Asya işgalini tamamlamasının ardından Kırgız topraklarında bulunan doğal kaynaklar sömürülmeye başlanmıştı. Türkistan kendi ekonomik

\footnotetext{
${ }^{91}$ Gömeç, age., s.103.

${ }^{92}$ Kuelgen, agm, Derin, agm, s.19.

${ }^{93}$ Wheeler, age., s.89.

${ }^{94}$ Manz, agm., s.286.

${ }^{95}$ Şimșir, age., s.220.

${ }^{96}$ Ziyayev, age., s.349.

${ }^{97}$ Kuelgen, agm.
} 
hayatını düzenleme ve zenginlikleri üzerinde herhangi bir yetkiye sahip değildi. Bölgeye çok sayıda Rus göçmen zorla veya mevki elde etmek için istekli olarak getirilmişti. Bölgenin coğrafyası ve iklimi Rusya'ya çok benzediği için genelde Rus ve Ukraynalı göçmenler burayı tercih etmişlerdi. Kırgızların elindeki topraklar alınarak bu göçmenlere dağıtılmıştı. Bu durum halk1 zor duruma düşürmüştü.

Neticede Türkistan her zaman için bir hammadde kaynağ 1 olarak görülecek ve her şeyden önce Rusya'nın ihtiyaçlarını karşılayacaktı. Bu nedenle Ruslar dikkatlerini Rus ekonomik politikasının temeli hâline gelen pamuk üretimi üzerinde yoğunlaştırmıştı. Pamuk üretimi artıkça hububat ekimi gittikçe azalmış ve neticede Rusya'ya daha bağımlı bir hâle gelinmişti.

Topraklarının verimli kısmı ellerinden alınıp Rus göçmenlerine verilen ve dolayısıyla Rusya tarafından sürekli artırılan vergileri ödeyemez duruma gelen Türk halkı, Rusların kuklası olan yerli idarecilerin yönetimi altında azap dolu günler yaşamışlardı.

Andican ayaklanması ayrıca dinî bir mahiyet arz ediyordu. İslam dininin hafife alınması, din adamlarının baskı altına alınması, ahlaksızlık ve yolsuzluğun toplum içinde özellikle geliştirilmeye çalışılması gibi insafsızca tutumlar halkı perişan duruma düşürmüştü.

Tüm bu gelişmeler ışığında Türkistan halkının yapılan haksızlığa tepkisiz kalması beklenemezdi. 1898 yılında Andican ayaklanması çıkmış ve ayaklanma hızla Hocent kasabasından diğer şehirlere yayılmıştı. Andican ayaklanması iyi planlanmamış ve organize edilmemişti. Bu nedenle isyan Ruslar tarafından bastırılmış ve isyana katılan çok sayıda insan öldürülmüştü.

Andican ayaklanması büyük öneme sahipti. İsyan kendiliğinden ortaya çıkmamış, ideolojik bir isyandı 1898 yılında gerçekleşen Dükçü İşan isyanı, Türkistan'daki boylar arasında kavmî bir birlik ve bağımsız Türkistan hükümeti oluşturma gayesini göstermişti. Halk bağımsızlık mücadelesi açısından paha biçilmez bir tecrübe edinmişti. Türkistan halkının tüm zulümlere ve baskılara boğun eğmeyerek haklı mücadelelerine devam edeceklerinin bir göstergesi olmuştu. Ayrıca bölgedeki sömürge iktidarının sarsılmasının ilk temeli atılmıştı. Andican ayaklanması önemli bir mihenk taşı idi. Çünkü Türkistan halkının kurtuluş arzusunun henüz kırılmadığının bir işareti olmuştu. 


\section{Kaynaklar}

Abazov, R. (2002). Çarlık Yönetimi Altında Kırgızlar. Türkler, C 18, çev. Özgür Çınarlı-Ahmet Karan, Ankara: Yeni Türkiye Yayınları, 607-614.

Allworth, E. (1944). Central Asia 130 Years of Russian Dominanace, A Historical Overview, Duke Üniversity Press, London.

Alpargu, M. (2002). “Türkistan Hanlıkları”, Türkler, C.8, Ankara: Yeni Türkiye Yayınları, 557605.

Arat, R. R (1977). “Kırgızistan”, İslam Ansiklopedisi, C:6 İstanbul: Millî Eğitim Yayınları, ss.735-741.

Babadžanov, B. M. (1998). “Dükči Īşan Der Aufstand Von Andižan”, Muslim Culture in Russia and Central Asia From the 18th to the Early 20th Centuries, Klaus Schwarz Verlag, Berlin.

Bacon, E. E., Esir Orta Asya, Tercüman 1001 Eser, İstanbul.

Bala, M. (1988). "Endican”, İslam Ansiklopedisi C.4, İstanbul: Milli Eğitim Yayınları, ss. 268270

Bigi, Muhammed Z. (2005). Mâverâünnehir'e Seyahat, Çev. Ahmet Kanlıdere, İstanbul: Kitabevi Yayınları

Bosworth, C. E. (1987). “Andejan”, Encyclopedia Iranica, Vol: II, London.

Caroe, Sir Olaf, Sovyet İmparatorluğu Sömürülen Topraklar, C.1, Çev. Zerhan Yüksel, İstanbul: Tercüman Yayınları

Derin, S. (2006). “Tasavvufun Orta Asya'da Yakın Geçmişteki Rolü: Kırgızistan Örneği”, İlmi Akademik Araştırma Dergisi, Sa: 16, s.7-39.

Djunushaliev, D. (2002). “Kırgızistan'da 1916 İsyanı”, Türkler, C.18, Çev. Alesker Aleskerov, Ankara: Yeni Türkiye Yayınları, ss.627-630.

Erdem, M. (2000). Kırgız Türkleri Sosyal Antropolji Araştırmaları, Ankara: Avrasya Stratejik Araştırma Merkezi Yayınları

Erşahin, S. (1999). Kırgızlar ve İslamiyet: Göçebe Bir Türk Boyunun İslamlaşma Tarihi Üzerine Bir Deneme, Ankara: Sek Yayınları 
Endican (1988), İslam Ansiklopedisi C.4, İstanbul: Milli Eğitim Yayınları, ss. 268-270.

Gömeç, S. (2011). Kırgız Türkleri Tarihi, Ankara: Berikan Yayınları

Hayit, B. (1995). Türkistan Devletlerinin Milli Mücadele Tarihi, Ankara: Türk Tarih Kurumu Yayınlar1, s.190-191.

Hayit, B. (1966). Esir Türkler: Türkistan'da Sovyet-Rus Sömürgeciliği ve Emperyalizmi, Asya'da Müslüman Halk Üzerinde Uygulanan Sovyet Sömürgeciline Bir Örnek, Ankara: Kişisel Kitaplar

Hayit, B. (2001). "Türkistan Çarizmden Bolşevizm Hâkimiyetine Geçiş Devrinde", Türkistan'da Yenilik Hareketleri ve İhtillaler 1900-1924, Ed: Timur Kocaoğlu, Haarlem, ss.179-190.

İnan, A. (1963). "Dükçü İşan İsyanı”, Türk Kültürü, Ankara: Türk Kültürünü Araştırma Enstitüsü Yayınları, sa: II, ss.10-12.

Kara, F. (2007). “Rusya'nın Kırgızistan'daki Koloni Siyaseti: 1852-1917”, Fırat Üniversitesi Sosyal Bilimler Dergisi, C:17, Sa:2, ss.329-340.

Kayaoğlu, Ş. (2005). "Rus Göç Siyasetinin Yeni Uygulamaları Karşısında Türkistanlıların Görevi”, Türkistan'ın Bă̆ımsızlı̆̆ına Hizmet Eden Yeni Türkistan'dan Seçilmiş Makaleler (1927-1931), Ayaz Tahir Türkistan idil-Ural Vakfi, İstanbul.

Khalid, A. (1999). The Politics of Müslim Cultural Reform Jadididsm in Central Asia, Berkeley: University of California Press

Konukçu, E. (1995). “Endican”, İslam Ansiklopedisi C.11, İstanbul: Diyanet Vakfı Yayınları, ss.190-192.

Kuelgen, A. Von (2004). "Andijan Uprising", Encyclopaedia Iranica, (http://www.iranicaonline.org/articles/andijan-uprising).

Kurat, Akdes N. (1987). Rusya Tarihi; Başlangıçtan 1917’ye Kadar, Ankara: Türk Tarih Kurumu Basımevi

MacGahan, İ.A. (1995). Hive Seyahatnamesi ve Tarihi Musavver, İzmir: Akademi Kitabevi

Manz, Beatrice F. (1998). "Central Asian Uprisings in the Nineteenth Century: Ferghana under the Russians", Russian Review, Vol:46, No:3, ss.267-281. 
Ömürbekov, T., “Sömürge Döneminde Kırgızlar”, Türkler, C:18, Çev. Liliye Sabırova, ss. 616626.

Pierce, R. A. (1960). Central Asia 1867-17914: A Study in Colanial Rule, California.

Saray, M. (1996). Yeni Türk Cumhuriyetleri Tarihi, Ankara: Türk Tarih Kurumu Yayınları

Saray, M. (2002). “Kırgızistan”, İslam Ansiklopedisi C.25, Ankara: Türkiye Diyanet Vakf1 Yayınları, ss.441-445.

Saray, M. (2002). “Rusya'nın Türkistan'da Yayılması”, Genel Türk Tarihi, C.9, Ankara: Yeni Türkiye Yayınları, ss.686-714.

Saray, M. (2004). Modern Kırgızistan'ın Doğuşu, Ankara.

Sertçelik, S. (2002). "Rus İmparatorluğu'nun Avrupa Yakasında Yaşayan Türklerin Demografik Dağılımı ve Çarlık Rusya’sının Türklere Yönelik Politikaları”, Genel Türk Tarihi, C.9, Ankara: Yeni Türkiye Yayınları, ss.614-639.

Şimşir, S. (2009). Dünden Yarına Türkistan'da Türkler, İstanbul: Kültür Sanat Yayıncılık

Wheeler, G. (1964). The Modern History of Soviet Central Asia, London.

Togan, Zeki V. (1981). Bugünkü Türkili ve Yakın Tarihi: Batı ve Kuzey Türkistan, C.1, İstanbul.

Ziyayev, H. (2007). Türkistan'da Rus Hâkimiyetine Karşı Mücadele: XVIII-XX. Asır Başları, Çev. Ayhan Çelikbay, Ankara. 